\title{
HIGH ALBANIA AND ITS CUSTOMS IN 1908.
}

\author{
BY \\ M. EDITH DURHAM.
}

[WITH PLATE XXXI.]

\author{
PUPLISHED BY THE
}

Ropal @ntbropological Inttitute of Breat obritain and Jrefand. 50, GREAT RUSSELL STREET, LONDON, W.C.

alifornia

rional

ility 
Social Sciences \& Humanities Library

Unversity of Caifuma. San Diego

P.ease Note:

Date Due

WAN $200 \%$

UCSD LID

तो 24,507

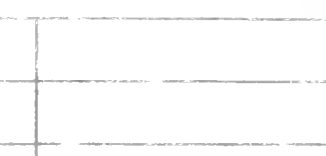




\title{
HIGH ALBANIA AND ITS CUSTOMS IN 1908.
}

\author{
By M. Editi Durham.
}

\section{[With Plate XXXI.]}

High Albania is the large tract of mountain land which forms the north-west corner of Turkey in Europe. It is the only spot in Europe in which the tribal system has been preserved intact up to the present day and along with it a mass of very ancient eustoms. Changes are now sweeping rapidly over the Balkan peninsula, and it is with the hope of inducing someone better qualified than myself to go and investigate on the spot, before it is too late, that I will try and give an idea of the very primitive conditions which still prevail. Writing has, it appears, always been an art unknown to the tribesman, consequently he possesses an extraordinary memory, and has handed down quantities of oral traditions, most of which remain to be collected.

Life is very rough, but the dangers of travel in North Albania have been ridieulously exaggerated. In most places I was received with enthusiasm. Many distriets dicl not remember having been visited by an Englishman, but had received a few Austrians or Germans; and a few had not admitted any foreigner at all for years. In such they only knew of the King of England vaguely, as one of the Seven Kings who are believed to squat in a cirele and arrange the affairs of Europe. One of the seven is the King of France, and one, I believe, the King of Polind.

The Albanian tribesman does not eall himself Albanian, but Shcypetaar, and his land Shrypmii. He says he is the son of an eagle (Shcypé), and his land is the land of eagles. His language grammatically belongs to the so-ealled Aryan group, and he boasts and believes that he is the oldest thing in the Balkan peninsulait was his before the eoning of the Slav or Turk, and he hates each with a bitter Balkan hatred. There is, I believe, no valid reason for doubting that he is the more or less direct deseendent of the ancient Illyrian tribes that dweit in the land when we first have record of it. Toman, Slav, and Turk have in turn held the Balkan peninsula. But the mountain tribesman has never been more than nominally conquered-and is still unsubdned. Empires pass over him and run off like water from a duck's back.

When I arrived in Scutari, Albania, the capital, travelling in the mountains was strictly forbidden by the Turkish Government, as the tribes were in almost 
open revolt. But as I knew the people and had good introductions, I took French leave, sneaked out of the town in the grey before dawn, dodged the gendarmerie outposts, and was soon safely away in very light marching order.

I visited in all some twenty-four tribes, and in many was lucky enough to get a detailed account of the tribe's origin.

These trilies are divided into several marked groups. The first group I visited was Maltsia e malle, the Great Mountainous Land. This consists of five large tribes and three small ones. Four of the five large ones each tells that its ancestor came from the north with his family, thirteen or fourteen generations ago, fiying from the advancing Turks. In some eases they foumd minhabited land and settled on it. In others, they fought with the men already on the land, and finally settled among them. These former inhabitants they call Anas, which is interpreted in the latest Albanian Dictionary as "aborigines." They tell that the Anas were very strong and active, conld leap over six horses and ate acorns and horseflesh.

They intermarried with the Anas. A few houses in the Hoti tribe still trace direct descent from the Anas, in the male line. All four of these tribes (Skreli Hoti, Gruda, Kilmeni) tell that their ancestors came from Bosnia or the Herzegovina, precise clistrict unknown.

An approximate chate for the coming of these immigrants is the founding of the chureh of Gruda, three lumdred and eighty years ago, so they say. Some of the tribes say they came rather before, and some rather after, this event. This gives the date 1528. History shows that, ronghly speaking, the tradition is probably eorrect, for the Turks killed the last King of Bosnia in 146:3, spreal gradnally over the land, and finally incorporated all Bosni: and Herzegovina in the Turkish Empire about 1590. The shifting of the peoples falls well within this period $(1463-1590)$.

The family, a communal of perhaps sixty or seventy members-such exist still to-day-would march slowly, rarely more than fifteen miles a day, and would be long on the way, the women carrying the burdens and driving the flocks. There would be an armed bodyguard of twenty or thirty fighting men, for at fifteen a tribesman is a fighting man, and often carries arms, and is no mean foe at twelve.

Many of the neighbouring tribes of Montenegro tell precisely the same talenamely, that their ancestors fled from the Turks thirteen or fourteen generations ago. Moreover, certain tribes of Maltsia e madhe and Montenegro actually acknowledge blood-relationship, and trace descent from a common forefather. I am very strongly inclined to believe that the present language and nationality of such tribes-that is, whether to-day they are Serbophone and Montenegrin, or Allanophone and Albanian-has been determined mainly by whether they came under the influence of the Orthodox Servian Church or of the Roman Catholic Church. There is some evidence to show that the people who eame down from the north were reither Orthodox nor Catholic, but belonged to the heretical 
Bogomil sect, which was wide spread in the Balkan peninsula in the Middle Ages. I was extremely interested to find that the Maltsia e madhe tribes, more especially the two, Skreli and Hoti, which say they come from Bosnia, the stronghold of Bogomilism, are freely tattooed on the hand, ar'm and sometimes breast, with designs that I at once recognised as common in certain parts of Bosnia, notably around Jaice, the old capital, where the last king was slain, and in these designs the sun and the crescent moon are almost always factors.

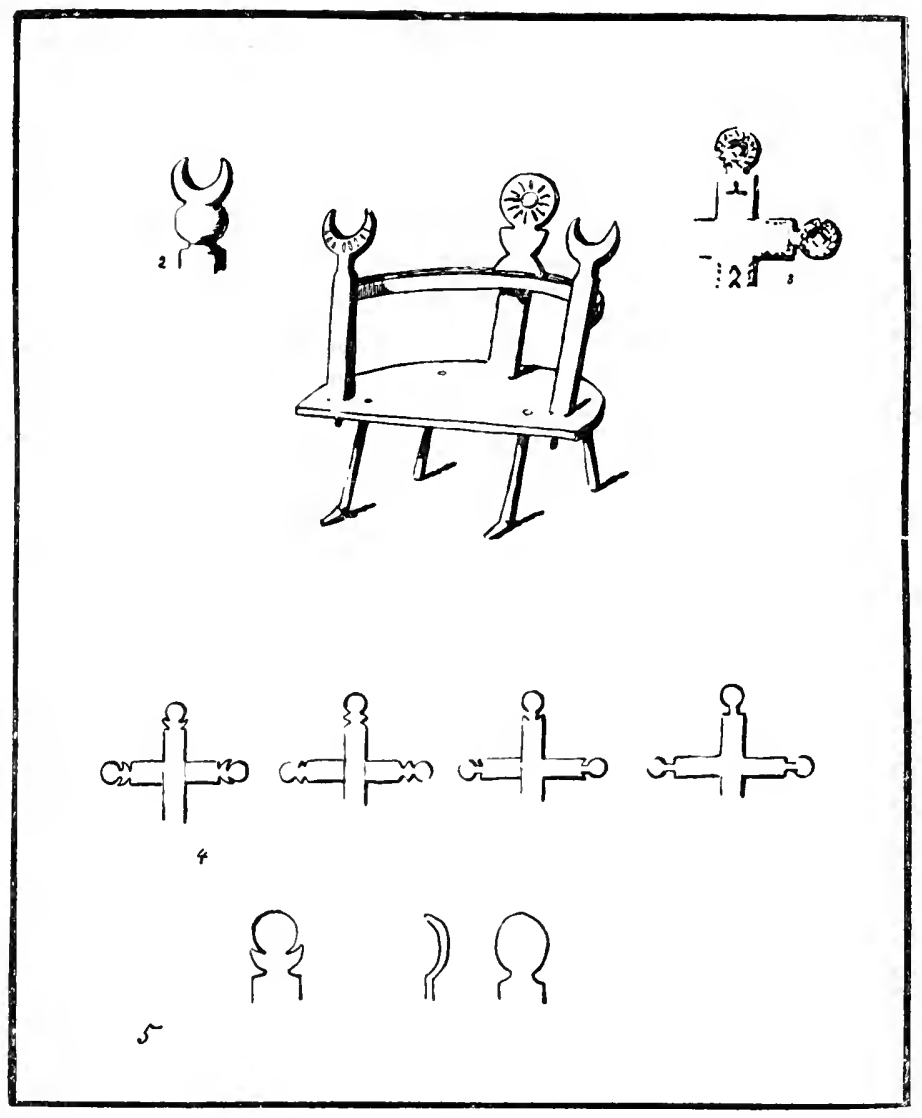

SUN AND MOON. N. ALBANIA.

Bogomilism was a form of Manicheeism, and in Manicheeism the sum and moon play a most important part. The Christian married women of Maltsia e madhe wear a crescent of silver filagree or of gold braid on their caps. They vow and declare that this has nothing to do with the Turk: "It is our custom. We have always done it."

You camnot live long with the up-country tribesman without finding that the religion he professes is the merest surface veneer. He is guided for the most part by mysterious superstitions and beliefs hidden in the recesses of his soul, and he cares no jot for priest or hodja when their teaching runs counter to his own 
Albanian ideas as to the fitness of things. He is a thorn in the side of all his spiritual pastors. He has often been execrated for the rapidity with which he will change his religion. Whole distriets have been known to turn Moslem suddenly, in order to score off a priest who has offended them. Nor do they become good Moslems. I have lived with Moslem tribesmen all night and all day, but I have never seen one pray or perform the ceremonial ablutions; and his women are all unveiled. So long as he is allowed to go on being Albanian in his own way the tribesman will assume any faith that is convenient. Islam lets hiin have his own way, consequently Islam is spreading. In some transition districts (e.g., Luria) people will go both to mosque and to chureh. If they don't get what they want from one they try the other.

To get at the real beliefs of either Moslem or Christian is most difficult, but I have it, on what I believe is very reliable authority, that many of the so-called Christians will admit to a belief in two conflicting powers of light and darkness, and also that the sun and moon, with which they tattoo, have something to do with this.

Twice during heavy thunderstorms I was told by my men that Kulshedra and Drangue (Drangoni) were fighting. Kulshedra is a female monster that strives to destroy humanity with torrents and tempests, and Drangoni is a male being who beats her back. Men and male animals can beeome Drangonis, and women, serpents, and other noxious ereatures Kulshedras. The tribesman has an intense belief in the innate depravity of all things feminine.

Fasting was much practised by the Bogomils, and the keeping of fasts most rigidly is the only law of the Catholic Church which the people strietly observe. These facts all point to lingering belief in a form of Manicheeism.

The second tribal group I visited was the Pulati group, ealled also Maltsia e rogel, the small mountainous land. Here also a tale of immigration is told by the more important tribes, but of immigration, not from the north, but from the east, the district known in earlier days as Rashia. These people tell that they arrived before the Maltsia e madhe people dicl. As the Turlss penetrated Rashia considerably before they suludued Bosnia, this tale also is probably true. They too tell that they found previous inhabitants who were a small dark people. In the tribe of Shala there are still eight houses that trace descent from these early inhalitants. The other families migrated in a body "a long time ago" to the neighbourhood of Dechani (probably at the end of the seventeenth century, when the Serbs left it in numbers and fled to Hungary). I remember, when at Dechani in 1903 , being greatly struek with the small very dark Albanians there, for I had previously linown only the fair type. There was fighting going on with the Turkish troops not far off, and the country was reckoned in a dangerons state, and a lot of these little dark men kindly eame and formed an armed escort for me when I went for a walk. Shoshi, the neighbour trihe to Shala, and consanguineous with it, tells the same tale, but here the small dark people have been wholly absorbel. They have, however, left their mark throughout l'ulati, where the number of small dark people largely exceeds that in Maltsia e madhe. 
The typical fair man, common in Maltsia e madhe and found in all the other districts, is a rather tall man with a yellow moustache, a fine cut aquiline nose and a long strong jaw. His eyes are grey or even quite blue. The bridge of his nose is narrow and his eyebrows slope downwards, often markedly so. His skin, where not sunburnt, is white. He is often a really fine animal, and very well aware of the fact.

The small dark man is insignificant in appearance, and usually an ugly little fellow. His eyes are brown, his hair grows low on his forehead. Sometimes a hairy line extends along the temple to the outer corner of the eyebrow, giving him an oddly monkey-like look. His skin is olive.

Fetween these two types there are, of course, any amount of links. The type which the Albanian himself considers Albanian is the fair aquiline type. From the high Albanian mountains right down to the Greek frontier the Albanian tells you " We are a fair people." And as he has never been worried by theories of dark and fair races, perhaps he knows.

The question, as to what these dark and fair races are, is a very difficuit one and I do not think my theories on the subject are of any value; so I will only give the statements of the people themselves and say that, roughly speaking, I founc the high Albanian tribes fall into three groups:-I. Maltsia e madhe, which tells of a large immigration from the north, and intermarriage with previous inhabitants: II. Pulati, with a tale of immigration from the east and similar intermarriage: and III. A group of tribes which tells of no immigration, and boasts that it has always been on the spot. This inchudes the Puka group, or part of it. The Berisha and Merturi men, who belong to this, vow that they have been there for ever. They also say that the Albanian is a fair man. It is noteworthy that in the districts where such a tale is told the place-names are all Albanian, save a few that appear to be Latin. In Maltsia e madhe, on the other hand, there are many Slavonic 1)lace-names.

An accident quite prevented my going to Merturi, but I visited the Berisha men, a most lively lot-the only ones that very nearly greeted me with bullets. Put that was because I came with men who happened to be "in blood" with them. I vainly tried to kodak them as they dashed from cover to cover, howling like hellhounds, and aiming at my men with their rifles. It was "touch and go," but they were very sorry afterwards, and we became great friends. They bronght me offerings of honey and rakia and begged me to stay at least a year, and I spent a week with them. These up-country tribesmen, who have rarely seen a foreigner (Berisha remembered one British consul and two Austrians), are very childlike, and change from one mood to another all in a minute. Berisha, so far as I saw, was mixed dark and fair, with a large proportion of dark.

Berisha and Merturi are important tribes, for they have overflowed and sent branches in many directions. The Merturi founded the town of Djakora about 400 years ago, and it is noteworthy that all the Djakova men that I met who claimed descent from Merturi were fair. 
Customs differ somewhat in these various groups. The Maltsia e madhe group is by far the most tattooed. It is also the fairest group. The darker Pulati people are very much less tattooed. We may perhaps deduce from this that the fair immigrant tattooed and the dark native did not. All throngh the tribes, whether lark or fair, I found the sun and moon symbols in one form or another.

I will now pass on to some tribal eustoms.

A fis or tribe in Albania consists of one or more barialis, that is, gromps of men that fight under one standard. Only one of these standards now bears a speeial tribe mark so far as I have learnt-that of the Mirdites of Oroshi, which has a rayed sun.

In some tribes all the bariaks trace descent from a common male aneestor, and the divisions have only been made for convenience when the tribe grew large. In other cases certain bariaks are of other blood, and have been adopted into the tribe for various reasons.

The tribes are strietly exogamous. That is, they invariably take wives from outside the tribe, excepting only when a barial within it is of different blood. Male blood only counts. (In a few eases it has been deciled by a tribe that certain bariak, thongh of common origin, are now sufficiently removed to be intermarriageable. But these are exceptions.) The rule is so strict that even tribes who trace origin from several brother's will not intermarry. Thus Shalah, Shoshi, and Mirdita are not intermarriageable. All descendants of a eommon male aneestor rank as brothers and sisters, and their union is looked on as incestuous and in the highest degree horrible. The offspring, I was repeatedly tolk, would be blind, deaf, dumb, deformed-all kinds of misfortunes would befall. There would be a curse on sneh a union, "for truly they are brothers and sisters, and it is forbidden to marry one's own blood." An exceptionally intelligent old Hoti man, a great authority on tribe law, when I asked how many generations mnst pass before Hoti could marry within the tribe, replied that "he hoped it would never be, for that even after a thousand year's the blood will still be that of Geg Laz (the tribe's forefather), and they would still be brothers and sisters, and to marry your sister is a great sin." So deeply rooted is the feeling that in all my eight months of wandering I heard of only one instance in which the law was broken. A girl eloped with a distant eousin on lier father's side. He was far enough removed for the Roman Church to marry them. But it was incest in the eyes of the outraged family. The luekless couple fled to another tribe for shelter, but were hunted down. The bridegroom was shot within the year, as was also his brother, who had aided the elopement and the bride's life was only saved by the intervention of the Franciscans. Tribe law is stem and mereiless.

Female blood does not eount at all among the Moslem tribes, nor did it till quite recently anong the Christians. Now the priests strive and partially sueceed in enforcing the Canon Law that prohibits the marriage of eousins to the sixth legree on botlı sides. Pope Clement VII, whose mother was an Albanian, sent the Arehbishop, of Antivari as Visitator Apostolicus to the Albanian mountains in 
1702. His report is a bitter lament. All the tribes, he says, are given over to pagan practices. "Among the execrable customs of the mountain people, the wretched parents are in the habit of buying young girls for a price for their sons who are of tender age, and of keeping them in their houses till of age to cohabit, and of omitting to contract matrimony unless a male child be born, even after fifteen years of sinful cohabitation." This shows that the Church then had no control over the marriagres, and the custom of not marrying legally till a male is born is not yet extinct.

As it has been the almost universal practice to take a wife from the tribe next door and to marry the resultant daughters back into it (unless of course the tribe be one that is consanguineous), it follows that certain tribes must be very closely inbred on the female side. So far as I could learn among the Moslems two tribes will go on exchanging daughters backwards and forwards for generations ( $\mathrm{I}$ ascribe to this practice the very marked type of the Moslem tribes); and it has only recently been checked among the Christians. But the people declare that such tribes are in no way related-have not one drop of the same blood. I said a child had some of its mother's blood, but they said, "No, only the father's."

The people all know most exact lists of their relatives on the male side. The fact that I could not enumerate my paternal cousins beyond second cousins was reckoned as a proof of the barbarous state of English society. "Just like dogs or" cattle." In fact, many of our habits, about which they perpetually questioned me, filled them with contempt or disgust, and they explained the superiority of their own.

Whatever may have been the origin of marrying outside the tribe it does not now at all depend on the fact, often noticed, that close living together tends to bring about prohibitory marriage laws, for tribe land is extensive, tracks very bad, and houses many hours distant apart.

It seemed incredible to me that tribe law should be so strong that, say, twelfth cousins should never desire to marry one another. In practice, however, they are rarely given the chance. All marriages are arranged by the elders, usually before the parties have reached maturity, and in a very large number of cases they are married before they have had time to make a choice. Marriage is entirely by purchase, except for the occasional forcible capture of a girl. Just before I went to Thethi, a bariat of the Christian tribe of Shala, they had had the effrontery to seize a Christian girl of Scutari when gathering sticks just outside the town and carry her off. Such however were her terror and misery that the local Franciscan induced them to release her unharmed. A girl was stolen too while I was in Skreli and supposed to have been sold to the Moslems of Krasnichi.

Most of the children are betrothed in infancy or in early childhood. Some even before birth. A inan, so soon as a son is born to him, seeks a suitable family with which to be allied, and should there be no daughter available, bespeaks the next one born. He often pays down part of the price as soon as she is born, and 
the balance later when she is handed over. The price in the richer tribes is from sixteen to twenty napoleons; in the poorer ones from ten to sixteen. It may be paid in money or its equivalent. A man too poor for anything better can swop an old rifle for an elderly ehildless widow.

Girls are married as young as thirteen and boys at fifteen, or even fourteen. But the age is rising. I found the more intelligent heads of houses in Maltsia e madhe objected to giving a girl under sixteen or allowing a youth under eighteen to have a wife, unless an extra woman was needed for the housework, in which case they said they would give a wife to a boy of sixteen. In such a case as this it is not unusual to give a boy a wife very much older than himself, possibly a widow, a strong full grown widow being needed. I met one case in which a boy of fifteen was married to a woman of twenty-five. Husband and wife had rarely or never seen one another previons to marriage. I never heard of a case in which a youth refused the bride provided for him. When I remarked on this, people said: "Why should he? A woman is a woman ; God has made them all alike." Of the girls they said cheerfully, "Oh! they get used to it after a week or two." Such a thing as romantic affection appears to exist but rarely.

A girl can escape the husband to whom she has been sold in one way only. Should she resolutely refuse to be married to him she may, by tribe law, swear perpetual virginity before twelve witnesses, and she is then free and has eertain privileges. In Maltsia e madhe she can inherit her father's land should he leave no son. From her it passes to the nearest heir male. She may dress as a man and earry arms, and often does so; she may also take blood vengeance as a man does: but this is seldom done, I believe.

Among the other tribes she cannot inherit land, which passes straight to the next heir male. He however must pay her yearly out of the estate 300 okas (about $650 \mathrm{lbs}$.) of maize, 18 olices of rakia, and 30 okas of wine. Sliould he fail to do so she can enforee payment by an appeal to the Council of Elders. Among these tribes I saw no virgins who wore male attire, and was told it was not customary. In Maltsia e madhe I met several. This practice of swearing virginity to avoid marriage with a man disliked prevails, I am told, among the Moslem as well as the Christian tribes. But I met no examples. I heard of one who had served in the Turkish army.

In all parts a sworn virgin is allowed to eat with the men and is treated as an equal, exchanges tobacco, and is generally "Hail! fellow, well met," in striking contrast to the position of a married woman.

No tribesman eats with his wife; and the odd custom still prevails of a married couple never addressing each other by name. To eat with a woman seems to be thought very degrading. The men eat first and the women eat up the bits left over afterwards at the other end of the room or, if Moslems, in their own quarters.

I was always treated with great honour and elassed with the buck-herd. No woman was allowed to eat with me in a tribesman's house. 1 ate with the men, 
but as they had to draw the line somewhere, they often helped my horse-boy first. Sometimes they would not even let a woman speak to me. They are tremendous talkers, and found a foreign female far too amusing to be wasted on their women. They also seemed to have an idea that as I am ummarried I belonged to the swornvirgin class and was fit to be associated with. Moreover both Albanians and Montenegrins have a proverb which says "Long hair, short wits-a woman's head!" and being a simple-minded folk they jump to the conchusion that the converse holds good, and eredit me with extraordinary intellectual power. This landed me often in very difficult positions, as the political situation was strained almost to breaking point, and I was called in to advise.

Among the Moslems I had to live night and day in the men's quarters, and even in the great chieftain's house of the Christian Mirdites no woman was allowed to come near me. I did not even see one, though I heard them scuftling behind the door to get a squint at me, but the men chivied them.

An Albanian tribesman, whether Christian or Moslem, has but one wife at a time, mless he choose to take as well his brother's widow. This by tribe law he may do one month after her husband's death. As all men of a tribe rank as brothers, it follows that a man may take his cousin's or uncle's widow, or both, shonld there be no nearer male relative than himself surviving. I heard of a case at Thethi in which a man had taken his uncle's and his cousin's widows, and wished to add a third and legal wife to his household - which caused conflict with the priest. This custom prevails everywhere except in Maltsia e madhe, where if it ever did exist (which I failerl to learn) it has now been extinet long enough to be considered incestuous, and I harl dinner with some men who had recently shot their brother-in-law for indulging in it.

In Nikaj, an outlying Christian tribe rarely visited by foreigners, this eustom is rampant, in spite of the frequent excommunication of guilty parties by the Franciscan mission-priest. Here and in several other places, as hell-fire was not enough to terrify them, I was asked to threaten them with the wrath of King Edward VII. I tried hard to learn the people's reason for this practice. When there is no child, and the husband has been shot very soon after marriage, there is no doubt that the idea is to beget a ehild that is to rank as his. Children so produced are still reckoned by many people as the actual offspring of the dead man, in spite of the Franciseans, who study medical works, and gravely assure their flocks that the thing is impossible.

Where children already exist, the arrangement is largely one of convenience. The woman must remain in the house to bring up the children. If there be an unmarried brother in the house he can thus obtain a wife without paying for hera great consideration in a poor family; also as one young man explained very earnestly the woman is to be considered. He was excommunicated, and so was all his communal household (eighteen persons), because of his relations with his cousin's widow. He said, "She has three children, so she must stay with us to bring them up, and so of course she camnot marry again." (It would be contrary 
to all tribe law to bring a strange man into the house.) "But she is only twentyfour, and to force her to live a single life would be very wrong. That is why I have taken her. I have a wife already, so I do not need her. I am sorry I am excommunicated, but I am an honourable man and I must act rightly to my cousin's widow."

A ehildless widow in Maltsia e madhe reverts to her own family, which can sell her again, and generally does so at once. In other tribes the husband's family has the right of keeping her. If they deeide to sell they divide the priee obtained with her own family.

A widow long married and childless is of slight value, as probably ineapable of child-bearing. A young healthy widow, married but a few months, is on the other hand snapped up at once, and often fetehes a higher price than a maiden.

There is a dearth of women in High Albania. The people declare that it is because God knows that many men will be shot, and so provides an extra supply. I believe myself that one of the reasons is, that owing to the very young age at whieh girls are married, there is a cruelly high death-rate in child bearing. But in some of the tribes where ehureh registers of baptisms and deaths have now been carefully kept for some years it really appears that a considerable excess of males is born and reaches maturity. Then the male death rate from gunshot wounds is high and thins them off a bit.

Life among the outlying Christian tribes is so primitive that I doubt if I ean make it understood. The communal family lives in a kula, a great stone tower two or three storeys high. It has no windows, only loopholes for rifles. It is often perched on a roek for better defence. The ground floor is a pitch-dark stable. The entrance to the dwelling is by a flight of stone steps to the first floor. An awful stench grips your throat. In pitch darkness you climb a wooden ladder to the living room up under the stone roof on which the sun blazes, making it as hot as a furnace. Thirty or forty human beings of all ages and both sexes are here erowded together. Here they are born and die, and here they bring their new bought brides without any kind of privaey whatsoever. The house is ruled by the Xoti $i$ shpis, the house-lord, and all the household obey him like dogs. If you ask why, they will tell you it is because he is the head-the right to rule is in his branch of the family-God made him head-if he is head of course you must obey. In some cases he still has power of life and death over his subjects.

The house is often filthy beyond all worls. Though the painted elests ranged round the walls may be full of fine embroidered clothes for festivals, and silvermounted pistols hang on the walls, the people are clad in dirty rags on whieh the liee crawl ealmly. The little children are often naked. The axe-hewn planks of the floor (made by cutting down a tree and then chopping all of it away till a plank of the right size is obtained) are caked with dirt and saliva. Two sheep or goats are tethered in a corner, fetlock cleep in dung. They bring luck to the house and promote its fertility. You sit on this floor or on a log. If there be a chair it is the throne of the house-lord and, especially in Shala and Shoshi, is possibly 
adorned with a carved sm at the back, and a crescent moon on either arm. Through the floor rises the hot reek of ammonia from the stables, and you are scarcely seated before a black clond of buzzing flies settles on you. The house-lord entertains you with elaborate ceremony. He makes the coffee himself. It is an insult to offer a guest coffee made by a woman. And abore all things the houselord is a gentleman according to his lights. He offers yon "bread and salt and my heart" (buk $e$ krype e zeme' $\left.t^{\prime} e^{\prime} m e^{\prime} n\right)$, which takes the form of rank sheep-cheese and rakic distilled from his own grapes. There are endless healths to be drunk, between each of which a bit of cheese is eaten. The rakia keeps down the cheese, and the cheese tames the rakia. If you are not prepared to undergo this ordeal do not enter a kula, for you will give dire offence. Hospitality is the law of the mountains, and the house-lord freely gives you of his best.

Amulets are freely worn to keep off the evil eye (Syy $i k e c)$. Albania swarms with devils and spirits $(O, e)$, magicians and witches (Shtriga). Women in Albania are all born wicked. In some districts probably quite half the women have dealings with the devil. But it is very hard to detect them. Shtrigas can work many wonders, bewitch a man so that he wither's and dies, or suffers aches and pains. A Shtrige can make herself quite small like a bee, and get into a house through the keyhole or under the door at night and suck a person's blood so that he fades and dies in time. The best safeguard is hard to get. A Shtriga always vomits the blood she has sncked. You must secretly track a woman you suspect to be a Shtriga when she goes ont to vomit the blood. You must scrape some of it up on a silver coin and wear it, and then no Shtrigc can harm yon.

Nothing is too marrellous for a tribesman to believe. Here is a good example, which the teller, a man from Djakova, believes most firmly. A young married woman who was pregnant craved for wine, but the family was too poor to buy any. Her mother-in-law, who was a Shtrigo, stripped the young wife quite naked and anointed her all over with a salve which she made, at the same time saying certain magic words. The young wife at once shrank to the size of a bee. "Go, my daughter" said the Shtriga, "to the cellar of old so-and-so, crawl in at the keyhole and drink all you want. But take care not to say the name of God." Off went the young wife to the cellar, entered and drank her fill. She then felt so much better that she cried "Thank God!" At once she became her natural size. "Oh what a dreadful position for a virtuous married woman," cried my informant with deep feeling, "to be in a strange cellar with nothing on at all!" There she had to stay till the owner of the cellar opened it next day. He was much surprised to find her, but as he was a very kind man, he lent her a coat to go home in and never doubted her explanation. And the Djakovan who told the tale knew the woman, knew the owner of the cellar, and had seen the keyhole. What more proof can you require? Moreover, as he remarked, how else can you explain the occurrence?

I saw a Moslem man who knew how to summon devils by hopping on one leg and waving the other behind him. But I was with Christian tribesmen, and such 
was their terror that he would cast a spell upon me that they would not allow him to come within a hundred yards of me, much less let me see him perform.

When a child is born you should break an egg over its face to keep off the evil eye ; and when a house is built you must kill a cock or a lamb and sprinkle the blood on the foundations. These two customs are still practised at Scutari, and the old fortress on the hill is one of the places, in the foundations of which a woman is said to have been built in the Middle Ages as an offering to the devils that destroyed it as fast as it was built.

At night in Albania the tracks are often infested with devils who take the form of flashes of fire, and no matter how well a man may know the way he cannot so on till the first cock crows and the devils disappear. A man I know who has been bothered in this way says it is no use to do anything but cross yourself and wait patiently for cockerow.

Save for an iron pot or two bronght from Scutari, and the coffee cups, everything used in the liulc is home made. The bowls, spoons, and troughs are hacked rudely from lumps of wood. The clothes are home spun and home wovell. The woollen stuff (stiak) is measured by the Kiut -the length of the forearm; the Perckili-that is the stretch of the thumb and index finger; the Shplak-the breadth of four fingers; and the Plam-the stretch of the thumb and little finger. Land is measured by the $A r$, as much, that is, as two oxen can plough in a whole day. Ar appears to be connected with the Latin arere. The Albanian for a plough is paimen, and to plough is me livrue.

Distance is measured by the hom only, and corn by the horse (kal), i.c., horseload. Riches are flocks and corn and weapons. To tribesman has much in corn. Maize and milk are staple diet. Meat on feast days when people eat like boa constrictors.

The tribes are all self-governing. The amount of independence they enjoy, and whether or not they pay fines or tribute to the Turkish Government, depends upon their fighting power and the more or less inaccessibility of the tribe land.

Tribe government is by a council (Hedjliss) of elcers. This varies in number according to the importance of the business in hand. In Maltsia e madhe a full council to deal with matters concerning the whole tribe consists of the Buriutitur (hereditary standard bearer), two Voyvodas, twelve elders specially chosen for their knowledge of tribe law, and seventy-two heads of houses. The term royroda is a Slavonic one, and does not occur in the other districts. Among the other tribes a full council consists of the Barialitar and the heads of all the chief houses. In certain districts, notably Shala and Shoshi, an active radical party has sprung up lately called the Dielmnii (yonth), which has elected its own head and refused to recognise the hereditary right in council of the Buriaktar. These new eouncils have passed some good modifications of tribe laws, and managed to enforce them.

The law of the mountains is known as the Canon of Lek Dukaghin. He was one of a chieftain family that ruled all Pulati, Puka, Mirdita, Luria, and Ljuma in the middle ages, and down to the taking of Scutari in 1479 by the Turks. Lek 
(Alexander), whose identity cannot be determined-there were several of the name and a mass of conflicting tradition-is regarded by the tribesmen with extraordinary awe. He is said to have come from Rashia with the ancestors of Shala, Shoshi, and Mirdita, and the present ruling family of Mirdita, now represented by Prenk Bib Doda, clains to be of Dukaghin blood. The tribes that were ruled by the Dukaghins still call themselves Dukaghini.

To Lek these tribesmen ascribe every law, almost every custom and habit that they have. That the bulk of the laws are, however, very much earlier than Lek's time is obvious. I am inclined to believe that the penalties chiefly are his.

To the tribesmen, however, all the so-called laws of Lek are as divine decrees; and especially does he believe that Lek ordered blood vengeance. Into the complicated rules of blood I have not space to enter. They dominate the whole life of the tribesman. Everything turns on ghak (blood). I have discussed it endlessly - for the family blood feud is the main topic of conversation-and collected a mass of cases.

It is usual for writers who do not know him to denounce the tribesman as a vulgar murderer, who kills wantonly for the sake of killing. But in order to understand a custom one must see it through native eyes. After living some eight months among blood-hunters, I perceived what ghak meant to them. It is not so much a punishment which they inflict, as an act performed for self purification, and as such a solemn and necessary act. For there are certain offences that blacken, not merely the honour of the man against whom they have been committed, but blacken also the honour of his whole house and even of his tribe. Only blood can cleanse the stain. And the man whose honour is blackened is obsessed with the idea of his own impurity. It gives him no rest. Blood he must have. In all the outlying tribes in which the blood laws are quite unmodified, male blood of the offender's house, even of a quite distant cousin, suffices; or if the affair be intertribal, blood of the offender's tribe. In such cases an absolutely innocent man who is ignorant of the cause of offence may be sacrificed; and his blood cleanses the other's honour, who, triumphant, announces his deed. He is now in turn liable to be shot, and should he have slain a man of his own tribe, by tribe law his house will be burnt, his corn burnt, and in some districts his trees felled and his cattle slanghtered too. But all this is of but small moment. His honour is clean, and if he must die he dies happy.

A man of the Christian tribe of Nikaj who was seeking blood was exhorted by the Franciscan to desist, and threatened with the torments of hell. "I would rather clean my honour and go to hell," he replied, and went out to slay. He slew, but was himself mortally wounded. The Franciscan hastened to the spot, and begged him to confess and repent while yet there was time. The dying man said, "I do not want your absolution or your heaven, for I have cleaned my honour." And he died.

We may regret that "his honour rooted in clishonour stood"; but there is a tragic grandeur about the man who is ready to sacrifice all he has, all that he 
holds dear, and even life itself, in order that he may do that whieh he believes to be right. It is not every one that is prepared so to act up to his ideals.

When you meet a tribesman and he drinks to you, Tu nghirit tjeter (long life to thee), remember to drink Tu nghiat me neers (long honour to thee) in return; for honour is better than life-in Albania.

\section{APPENDIX.}

\section{Table of tife Trises of Nortil Albania.}

\section{Maltsia e Madhe Group. (Great Monntain Land.)}

I. Gruda.-A tribe of one bariak, situated between the River Tsem and the Montenegrin frontier. North of it is the Knchi tribe (Montenegro), and south the Hoti. Gruda consists of about 500 houses (a house is vaguely reckoned in Maltsia e madhe as eight or ten persons). Of these eighty trace descent from Berisha (see below), and the remainder, who are ealled Gell (? Djell), are immigrants from the Herzegovina. They state that the ehurch of Gruda was built 380 years ago, shortly after their arrival. Gruda is now about half Moslem and half Catholic. The Berisha and Djell stocks are intermarriageable.

II. Hoti.-A large tribe situate south of Gruda and extending to the shore of Scutari Lake. On the east it is divided from Kastrati by the Licheni Hotit, an arm of the lake. It consists of one bariale of about 500 houses. All are Catholic but three, those of the Bariaktar's family. This turned Moslem seven generations ago. All Hoti, except twelve houses, traces deseent from Bosnia. These twelve are called Anas, and are of unknown origin. They were there when Hoti came.

Shortly after the building of the ehurch of Gruda, thirteen generations ago, Geg Laz, the ancestor of Hoti, arrived with his family. Geg was one of four brothers. The others were Piper, Vaso, and Krasni. From these descend the Piperi and the Vasojevichi of Montenegro, who are Serbophone and belong to the Orthodox Church. Krasni is ancestor of the Krasnichi, now Moslem and Albanophone (see below). Hoti is consanguineous also with half the Triepshi tribe, which branched from it later, and reckons consanguinity also with part of Nikaj beeause it branehed from Krasnich, which is consanguineous. Marriage is, therefore, prohibited with all these. Hoti intermarries with the Anas, but mainly marries with Kastrati.

III. Kastrati.-Consisting also of about 500 houses, lies between the Licheni Hotit and the Skreli tribe. 300 houses trace deseent from one Delti or Dedli, who came with his seven sons from the bariali of Drekalovich of the Kuchi. This in turn traces origin from Berisha (see below). The other 200 houses trace from people already on the spot when Delti arrived. They are said to have been Slavs. All are now Albanophone and the majority Catholic, the rest Moslems. 
IV. Skreli is situated in the valley of the Proni Thaat. It is mainly Catholic, and traces its origin from Bosnia. It is one bariak.

V. Kilmeni.-A very widely-spread tribe of four bariaks-Seltze, Vukli, Boga, and Nikshi. These descend each from one of the four sons of Kilmeni, the ancestor of the tribe. He arrived in the land about thirteen generations ago. Nevertheless, these four barialis are now considered sufficiently far removed to be intermarriageable, and marry freely. This is exceptional. Kilmeni came vaguely "from the north." Seltze (300 houses, all Catholic) lies at the head of the valley of the Tsem Seltzit, one of the sources of the 'Tsem. The majority of the houses, Djenovich Seltze, descend from Kilmeni. The rest, Rabijenovich Seltze, are of other stock, some say from near Rijeka in Montenegro.

Vukli lies at Tsem's other source, Tsem Vuklit. It is ninety-four families (number of persons to a family unknown), all Catholic.

Boga lies at the source of the Proni Thaat. It is seventy-five families, almost all Catholic.

Nikshi (15t houses, almost entirely Moslem) lies between Vukli and Boga.

Kilmeni is migratory. It descends in large numbers to the plains near Alessio to pasture flocks in the winter, and returns to the mountains for summer. It has thrown out branches in several other districts (see below).

V'. Lohe (or Lolija). - A small tribe of one bariak, consisting of eighty Moslem and forty Catholic houses.

VII. Rechi, also small, and mostly Moslem. Rechi and Lohe are said to be of mixed origin from Shlaku and I'ulati. Probably overflows of those districts.

VIII. Kioli, small Christian tribe. I passed through quickly, and did not learn its origin.

These three all lie between Skreli and Pulati, and the whole eight form the Maltsia e madhe group, and are included in the diocese of Scutari.

It is noteworthy that there is a sprinkling of Slavonic names throughout Maltsia e madhe.

On the shore of the Lake of Scutari, north of Scutari, is a small Moslem tribe, Kopliku, and between it and Lohe the small Moslem tribe Grizhi. Between Kopliku and Scutari is the orthodox Serbophone village of Vraka, the only Serbophone district in Albania. It is of mixed descent from refugees from Bosnia and Montenegro, who fled from blood. It reckons about 1,000 souls.

\section{Pulati Group.}

Pulati is difficult to define, as its ecclesiastical limits (the diocese of Pulati) extend farther than the tribes actually called Pulati by the people. Lower Pulati, or Pulati proper, includes four tribes.

I. Ghocenni-A small Catholic tribe of one barial:

II. Plani.-A Catholic tribe of one barial, tracing origin from three stocks which are intermarriageable. One descends from Kilmeni $(q . v$.$) .$

III. Mgula.-Small Catholic tribe, one barials. 
IT. Kiri-Catholic tribe of one bariak.

The other tribes included in the diocese of Pulati are :-

V. Shala.-This is a very large and extensive tribe, occupying all the upper part of the valley of the River Shala, and reaching to the summits of the mountains that form the watershed on either side. Shala consists of four barials, Thethi, Petsaj, Lothaj, and Lekaj. All descend from a common ancestor. Three brothers are reported to have fled from Rashia when it was overrun by the Turks (this would be at the end of the fourteenth or beginning of the fifteenth century). One had a saddle (Shala), the other a winnowing sieve (Shosh), and the third nothing: so he said Mir dit (good-day) and went off. This is the legendary origin of Shala, Shoshi, and Mirdita. They still reckon that they are too nearly related to be intermarriageable. The barial. Thethi occupies the head of the valley. It consists of 180 houses, all Catholic. (A house in all Pulati averages many more inmates than in Maltsia e madhe, as the custom of large communal families prevails. There may be as many as forty, or even more.) Thethi is self-governing, and is almost independent of the rest of Shala. Petsaj, Lothaj, and Lekaj are said to have separated into three main houses 376 years ago. They are now barialis. Lothaj and Lekaj have quite recently decided that they are far enough removed to be intermarriageable. Thethi and Petsaj will not intermarry within the tribe. Shala tells that, when it arrived in the land, there were already small dark people inhabiting it. With these they intermarried. Eight houses near Abate, lower Shala, trace origin from these earlier folk. The rest of them emigrated to Dechani. Shala is entirely Catholic.

VI. Shoshi.-Origin as above. It lies south of Shala on the right bank of the Shala River.

VII. Toplana.-Is a small Catholic tribe of one bariak lying east of Shoshi. It is in a very wild district, and has the highest death-rate from gunshot wounds of all the Christian tribes. It tells that it is very old.

The whole district occupied by the above tribes is called Maltsia e vogel, the Little Mountain Land. Also included in the diocese of P'ulati is :

VIII. Nikaj.-This is an offshoot from the Moslem tribe of Krasnich (brother to Hoti, q.v.). Its ancestor Nikol left Krasnich while Krasnich was yet Christian. (Catholic or Orthodox ?). One hundred houses of Nikaj, the Tsuraj, trace descent from a daughter of Nikol who bore an illegitinate son by a gypsy which Nikol adopted. This is the only case of female descent I heard of. Nikaj is all Catholic. It is one of the wildest and most poverty-stricken of the tribes.

\section{Puka Group.}

Puka is a very large tribe of seven buricks:-

Puki.-All Moslem. Cheriti.-Part Catholic, part Moslem. Chiri.-All Catholic. Dushaj (?)-All Catholic. Komani.-Catholic. Kabashi.-Moslem. And Berisha with Merturit-Gurit, all Christian. These two last are entirely Catholic. They tell no tale of immigration, but claim to be among the very oldest inhabitants. (See Gruda ante.) 


\section{Postivipe Groun.}

Muzrciu.-A small Catholie tribe on the Drin, east of Scutari.

Drishti._All Moslem, small tribe.

Shlaku.-Tribe of one barick, on right bank of Drin, all Catholie. Traces origin from Toplana (q.v.).

Dushmani-A Catholic tribe of two barials:-Dushmani (160 houses) and Temali. It takes its name from one Paul Dushman, who was chieftain in the fifteenth century.

Suma.-A largely Catholic tribe on the right bank of the Kiri. All these are included in the Diocese of Pulati.

\section{Mirlita.}

The largest and most important tribe of all. It is wholly Catholic, and has an independent ecclesiastical head, the Abbot of Mirdita; and an hereditary Prince of the whole tribe, Prenk Biba, called Prenk Pas. It consists of five barickis.

Of these three, Oroshi, Spachi, and Kushneni, trace origin from the original ancestor who fled from Rashia. (See Shala, ante.) They are therefore consanguineous and not intermarriageable. Nor do they marry Shala or Shoshi. They marry chiefly Kthela and Luria.

The fourth bariak, Fandi, belonged to the Ijuma group, but left it when Ljuma turned Moslem and joined Mirdita. The fifth bariak Dibri (not to be confounded with the Moslem Debra of the Ljum group) is also of another stock. These two bariaks are therefore marriageable with the first three.

Mirdita in all reekons 3,000 houses, with an average of ten souls to a house. The three first buriaks state that the Pestriku mountains were their original home.

\section{Kithele.}

With Mirdita in war marehes Kthela. Mirdita and Kthela have the right to lead in all wars with the sonth. Hoti leads in all wars with the north. Kthela is a large tribe of three brivils:-Kthela, all Catholic; Selati and Pelati, both mixer. Mohammedanism is sprealing.

$$
\text { Hoslem Tribes. }
$$

The wholly Mostem tribes nearly all lie to the east of the large Christian tribes, and occupy the lower lying and more fertile lands where the mountains sweep down towards the plains. They are reluetant to admit strangers to their territories, and very suspieious of questions.

\section{Debre Group.}

I. Latria.-Is the head tribe of this group, one bariak, 200 houses. In twenty there are still some Christians. No house is entirely Christian, and Islam is making quiek progress. When (hristian (recently) it intermarried considerably with Mirdita. Now marries the two other tribes of the group, Matija and Debra. 
II. Matija.-Wholly Moslem; I did not visit it. It is said to consist of 1,200 houses, and covers much land.

III. Debra.-All Moslem. I did not visit it. These three tribes are among the most independent of all.

It is noteworthy that Luria in the middle ages formed part of the Dukaghin principality, while Matija and Debra, it would appear, owned allegiance to Skenderbeg.

IV. Arnji-A small independent Moslem tribe on the left bank of the River Mola. It is an offshoot from Berisha. Women wear Mirdita dress.

\section{Prizren Groutp.}

I. Ljuma.-A large and very independent Moslem tribe.

Along with it are grouped, Bruti, Mal i zi, Rechi, Vlas, and other small districts. They are all offshoots, so far as I could learn, of various Christian tribes, c.g., Shala, Fandi, etc.

\section{Djakora Group.}

I. Iashi.-S00 houses, all Moslem. Did not visit it.

II. Tropopoja._-300 houses, all Moslem.

III. Hashi.-Very large tribe vaguely reckoned at from 600 to 1,000 houses. Almost all Moslem. Occupies the Pestriku mountains which are the traditional home of the Mirdites (q.v.). Are not consanguineous with Mirdita.

Djakova and its immediate neighbourhood is almost entirely populated by offshoots from Berisha, Shala, Fandi, and Mirdita. These all recognise consanguinity with their mother tribe and do not intermarry with it.

\section{Ipek Group.}

This consists of Ipel; Gusinje, and Plava.

I. Ipch.-Albanian population from a number of stocks. In neighbourhood a number of Serb Orthodox villages. Also Albanian villages, some hailing from Shala and Berisha. At Dechani, the dark stock from Shala (q.v.).

II. Gusinjc.-All Moslem except a small Serb Orthodox population. Gusinje has never been Catholic. Much of the Moslem population can speak Serb. Stock very mixed.

III. Placu.-I did not visit. Said to be of mixed stock, some from Hoti (q.v.), some from a very old stock called Pagani.

\section{Note on tie 'rimes Consanguineous with Hoti.}

I. Krasnich.-I could not visit this tribe, as it was badly at blood with all its neighbours, and objects also to all foreigners. It has a powerful chieftain, Shaban Benaku, who traces direct descent from Krasni the brother of Geg Laz, ancestor of Hoti. It is noteworthy that Krasan is Serb for "beautiful," Krasnil, "a handsome man," for the tribe stems from Bosnia Also, that though now all Moslem Krasnich 
men will go to the Serb Monastery Chureh of Dechani for holy bread, so do the Catholics of Nikaj who are consanguineous with Krasnich. A Scutari man, who managed once to penetrate Krasuich in disguise, told me the plot of a long ballad he heard sung there which struck him much. It is precisely the same as one published in Serb among the collected ballads of Bosnia.

II. Piperi.--In Montenegro, all Orthodox and Serbophone; did not throw in its lot with Montenegro till 1790.

III. Vasojecich.-Is since the Treaty of Berlin lualf Montenegrin and half mnder Turkey. Is all Orthodox and Serbophone. It is noteworthy that in the Montenegriu part many Albanian proper names oecur with Serb terminations, ¿.g., Dedich and Dedovich. Ded = Domenic in Albania.

Other Montenegrin tribes consangnineous with Albanian ones:-

Bijelo Pavlich.-One of the largest Montenegrin tribes, also joined Montenegro in 1790. It traces origin from Bijelo Pavlo (White Paul), one of the Dukaghins of Mirdita, known in Mirdita as Pal $i$ bardh. The tribe is all Orthodox and Serbophone.

Kuchi.-Kuchi has been ineluded in Montenegro since 187\%. It fought on the Montenegrin side in the last war. One of its baikaks, Drekalovich, traces direct descent from Berisha in Albania. It is now, I believe, all Serbophone.

Example of a Pedigree from Hoti, High Albania.

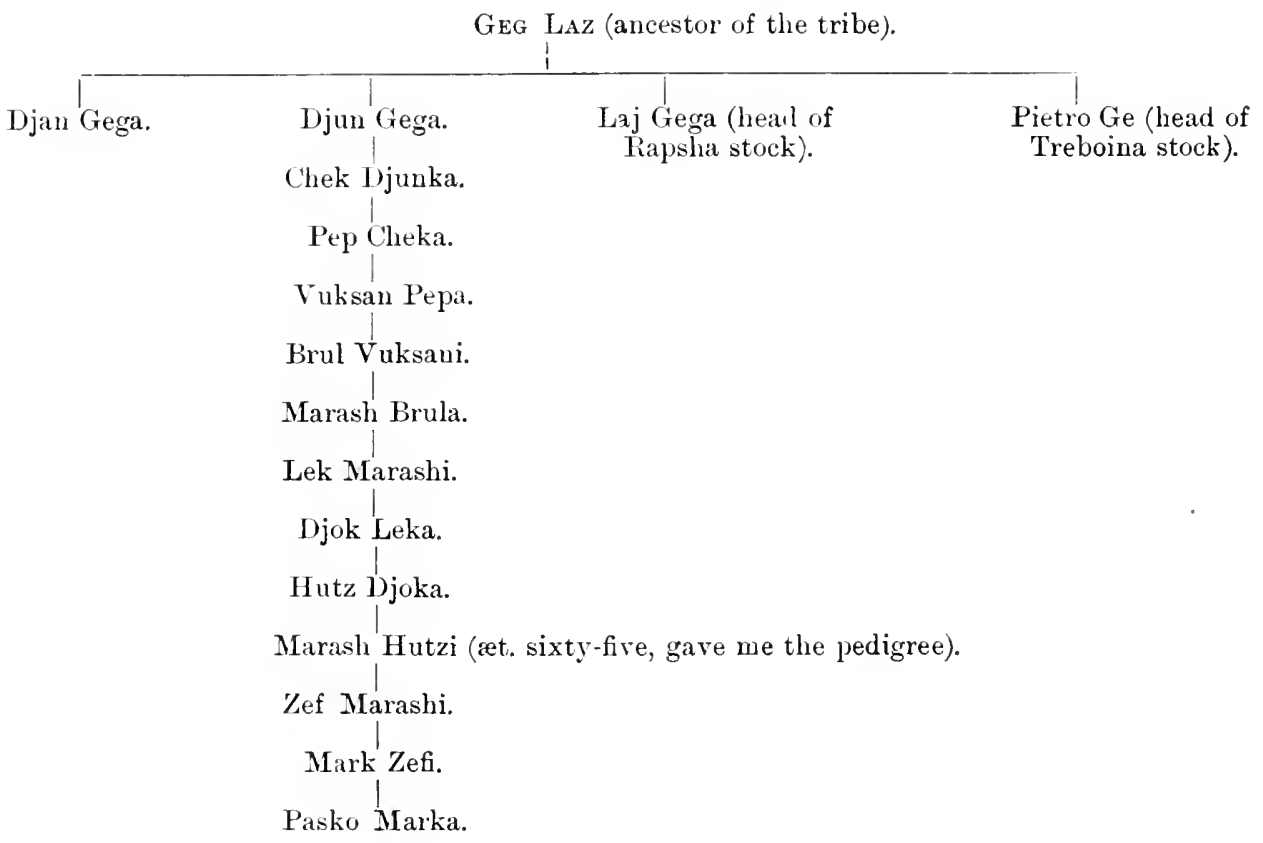


Description of Illustration on 1.455.

Fig. 1.- "Sun and moon" chair, Shela.

, 2.-Variant design of arm end.

" 3.-Cross-terminating in "suns," Thethi.

" 4.- Series of common wooder crosses showing all stages of pattern.

, 5. - Wooden headpost and head and footposts of Moslem graves (Hashi and Puka).

\section{Description of Plute XXXI.}

Fig. 1.-Nus. 1-7. Tattoos common among the Christians of the tribes of Maltsia e madhe, N. Albania.

, 8-11. Common tattoos (Roman Catholic), Bugojuo, Bosnia.

, 12-17. More elaborate examples from Jaju, Bosnia.

, 18-23. Bosnian tattoos collected by Dr. Truhieka-

No. 18. The ear of corm.

" 19. "Ograda," the palisade.

,20. "Kolo," the circle.

,21. The moon.

Nos. 22, 23. The cross.

"2.-Gravestones in Roman Catholic graveyard, Dushmani, F. Albania (showing variants of cross, crescent, and sun-all recent). 

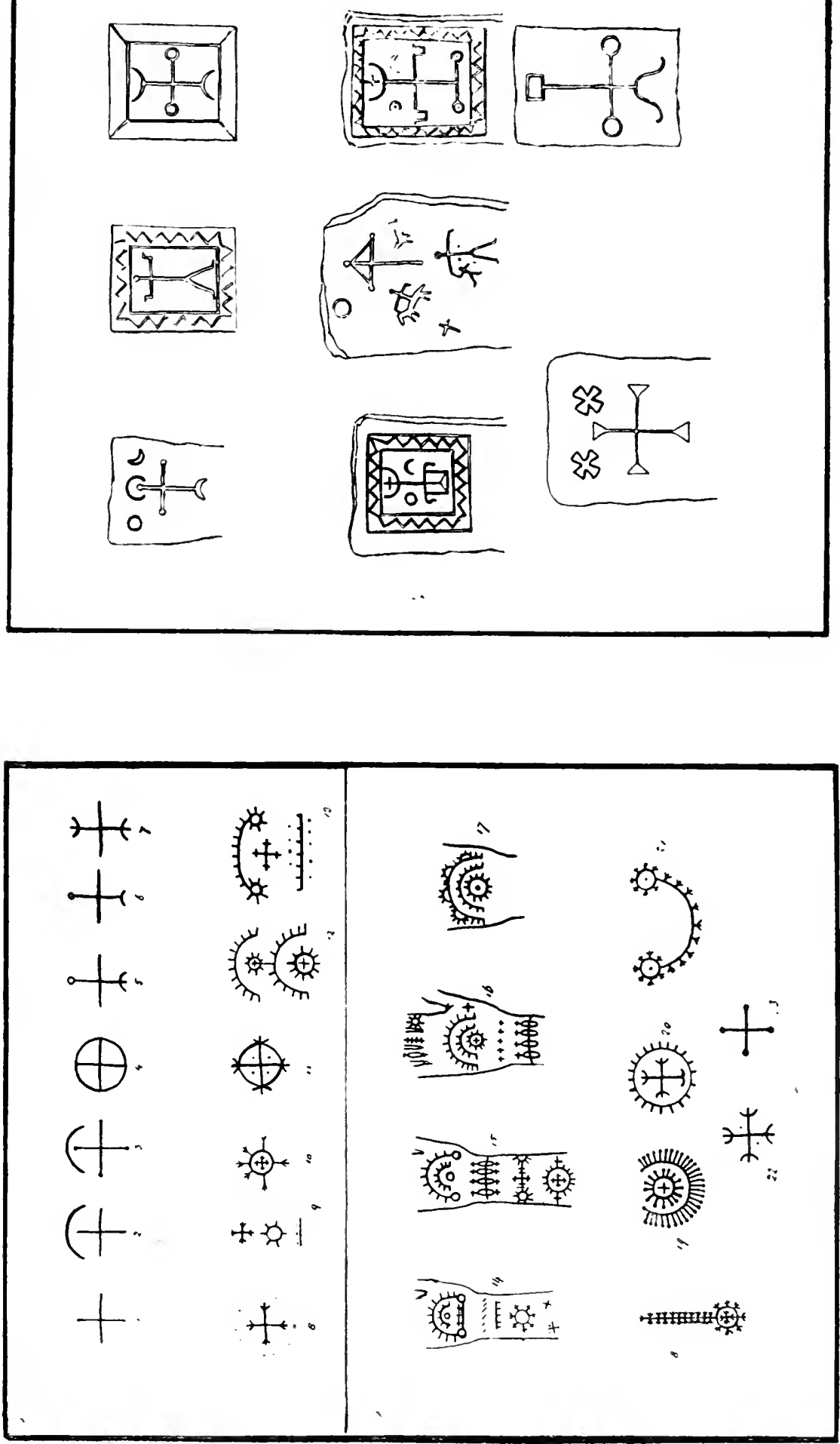
University of California SOUTHERN REGIONAL LIBRARY FACILITY 405 Hilgard Avenue, Los Angeles, CA 90024-1388 Return this material to the library from which it was borrowed. 


\section{ROYAL ANTHROPOLOGICAL INSTITUTE OF GREAT BRITAIN AND IRELAND.}

This Institute was established in 1871 by the amalgamation of the older Anthropological Society and Ethnological Society. It has for its object the promotion of the Science of Mankind-Anthropology-by the accumulation of observations bearing on man's past history and present state in all parts of the globe. It investigates, in a rigorously exact manner, everything that can throw light upon the laws of man's nature: his origin, history, and capabilities of progressive development and civilisation, It studies him structurally and psychologically, under the several types in which he is found in various regions; and comparatively, in relation to the rest of the animal kingdom The ultimate object of the Institute, therefore, is to build up a Science of Man on a basis of well-ascertained fact, and logically deduced inference. As means to this end, the Council of the Institute has adopted a plan of operations, the principal heads of which are as follow :-

1. Meetings for the reading of papers and for discussion of anthropological questions.

2. The issue of a Journal containing Reports of the Proceedings at the Meetings, with other matters of anthropological interest.

3. The appointment of Local Correspondents in all parts of the world to collect information, and to aid the Institute in its operations.

4. The maintenance of a library, which contains sets of all the principal Anthropological Journals published in the United Kingdom or elsewhere, besides a large and valuable collection of books of reference, travels and researches, an extensive collection of photographs and lantern slides, and much unpublished material for the use of students of Anthropology. Fellows residing in the country, as well as in London, can borrow books from the library.

5. The appointment of Committees to conduct special investigations, as occasion offers, in the various branches of Anthropology.

6. Co-operation with the British Association for the Advancement of Science, and with foreign scientific societies in anthropological investigations; co-operation with individuals and institutions in aid of explorations and in the establishment of local centres of anthropological study; and, generally, the stimulation of individual and local efforts to further the objects of the Institute.

The annual subscription is Two Guineas, which is due on election (unless such election takes place in the month of November or December) and on the 1st of January in each succeeding year. A Member may at any time compound his future subscriptions by the payment of $£ 3110$ s.

Persons who wish to become Fellows of the Institute are requested to communicate with the Secretary, 50, Great Russell Street, W.C. 